\title{
ESTIMATION OF COST OF CAPITAL IN EMERGING MARKETS: THE CASE OF ESTONIA
}

\author{
Mark Kantšukov', Jana Loemaa ${ }^{2}$ \\ ${ }^{1}$ University of Tartu, Estonia, ecomark@ut.ee \\ ${ }^{2}$ Estonian Business School, Estonia, jana.loemaa@ba.ee \\ cross'ref http://dx.doi.org/10.5755/j01.em.17.1.2254
}

\begin{abstract}
This paper analyzes the practice of the cost of capital estimation by Estonian financial analysts based on the survey conducted by authors. The cost of capital is an important input in many financial models, especially when dealing with business valuation, optimizing company's capital structure, and others. In spite of numerous studies on the issue and quite a period of cost of capital estimation, which is over ten years, Estonian analysts are faced with difficulties of finding appropriate inputs to estimate the cost of capital for Estonian companies. We find that the practice of cost of capital estimation is rather diverse albeit there are common approaches used. The primary approach to estimate the cost of equity is capital asset pricing model (CAPM), whereas there is no prevalent approach to estimate the cost of debt. Majority of analysts account for the country risk, the practice of accounting for other risks is scattered. Finally, we notice emergence of new approaches to cost of capital estimation.

Keywords: cost of capital, companies valuation, survey analysis, emerging markets.

JEL Classification: G24, D32.
\end{abstract}

\section{Introduction}

The cost of capital is an important input for many financial models, especially those dealing with business valuation. It is also an important concept for capital structure related decisions. All in all, the purpose of corporate financial management is to maximize the wealth of company's owners which is equivalent to minimization of company's cost of capital.

The objects of this paper are Estonian financial analysts who deal with business valuation

The aim of this paper is to evaluate the practice of cost of capital estimation by Estonian financial analysts.

The tasks of this paper:

- To give an overview of nature and relevance of the cost of capital

- To present the most widespread methods and approaches to cost of capital estimation

- To give a brief overview of previous research on cost of capital issue

The methods were applied:

- Analysis of scientific papers about cost of capital and classical textbooks on corporate financial management

- Development of a survey questionnaire

- Survey of financial analysts.

\section{Nature and relevance of the cost of capital}

Albeit the term and the concept of the cost of capital has been discussed in Estonian financial environment over the last decade, its nature and importance may still be vaguely perceived or misused by financial specialists. Generally we may think of cost of capital as the payment made by a company for using capital.

There are numerous asset valuation instances which require cost of capital estimation. The need to make valuation for selling and purchasing purposes is one of the fields of cost of capital application.

Today, traditional definition of cost of capital is the opportunity cost of investing money into the next best alternative at the same risk level. Because the market offers a variety of alternatives to investors, the company's cost of capital should be benchmarked against those alternatives (Bruner 1998). The concept of cost of capital has its importance in the framework of company or project valuation, in which a company seeks to create value to its shareholders. The cost of capital should be estimated in order to learn how much of wealth a company built in excess of capital cost. In this context the valuation tells how much a company paid for using its capital and, therefore, how much it earned in excess. As investment supposes estimation of its profitability, the notion of cost of capital becomes inevitably linked to the valuation process as it allows estimating investment's profitability and economic feasibility. 
Expounding the notion of capital, company's capital can be split into two sources, which are owner's equity and debt. Most often, companies are financed with at least two sources of capital. Not surprisingly, each source would have a different cost. For instance, to an investor, debt capital may seem more attractive and less risky than equity. The law provides that in case of company's bankruptcy creditors shall be paid first and then shareholders be paid. In contrast, equity holders enjoy higher risks as they have a claim on residual cash flows. Besides, interest payments on debt are traditionally made on a regular basis, whereas dividends and profit distribution enjoyed by equity holders is not. Deciding to take a risk, investors ask for higher payoff for an investment, causing the risk premium to increase. Thus, the sources of capital are diverse and the risks associated with them differ from asset to asset. The divergence of costs prompts for the need to investigate the set of alternatives applied in the real world to estimate those costs and to analyze their integrity and applicability in specific conditions.

\section{Methods and approaches to cost of capital estimation}

Theoretically, in an efficient market investors hold market portfolio which captures fractions of companies' equity and debt, thus being subject to the risk created by those companies. Investors thus enjoy the risks arising from assets in their portfolio. Because cost of capital is the price of financing, it equals the rate of return required by investors who hold that asset, either equity or debt. In turn, cost of capital is the function of risks posed by an economic sector and other economic variables. Vernimmen (2005) distinguishes between three approaches to cost of capital calculation which are: (1) direct method via company's beta, (2) indirect method via the WACC, and (3) deducted method via enterprise value.

Direct Approach to Cost of Capital Estimation. The direct approach relates to the Capital Asset Pricing Model (CAPM), which infers required rate of return via asset's returns deviation from the market return. The CAPM has its roots in the 1960s, elaborated by W. Sharpe and J. Lintner. In fact, the CAPM was developed in the light of portfolio theory of H. Markowitz in the late 1950s to estimate investors' returns on their portfolio investments. The CAPM is confined to numerous assumptions and thus constraints, which are not always feasible in the real world. The idea behind CAPM lies in the market efficiency, implying that market stays in its equilibrium stage, in which all investors have access to the same information and thus possess similar expectations about their contingent returns (Armitage 2005). Market efficiency implies straight linear relationship between the risk and return, which means that investors are compensated for taking additional risks by increased returns Sharpe (1964). Sharpe (1964) named this 'the price of risk'. The study of Modigliani and Pogue (1974) cited by Copeland (1988) additionally pointed that different industries have a different risk-level. In other words, linear relationship between risk and return holds true with the only difference that some industries plot flatter and others plot steeper relationship. Beta also depends on the operating structure of the business (Vernimmen 2005). At high fixed costs returns fluctuate greatly, and thus beta is higher; on the contrary, at high variable costs returns are less sensitive to the market movements. Moreover, as investors are price-takers, no additional costs shall be incurred if they diversify their investments (Damodaran 2002). The standard formula used to express the Capital Asset Pricing Model is the following:

$$
E\left(R_{A}\right)=R_{F}+\beta_{A}\left(E\left(R_{M}\right)-R_{F}\right)
$$

where $E\left(R_{A}\right)$ is expected return on a risky asset

$R_{F}$ is risk-free rate

$\beta_{A}$ is measure of systematic risk

$E\left(R_{M}\right)$ is expected market return (Armitage, 2005)

According to McLaney et al. (2004), as the CAPM derives cost of capital from capital market, it allows to assess the impact of various factors on asset's value. The impact is assessed via market risk premium which is then adjusted to the covariance of the security with the "generality of the risky investments" (McLaney et al. 2004), or the $\beta$ coefficient. As a matter of fact, Armitage (2005) stresses that CAPM is just a model, which explains the relationship between the variables, provided conditions are satisfied. The market risk premium and the risk-free rate are exogenously given and are thus not explained by the model (Armitage 2005), whereas the measure of systematic risk is calculated using equation.

The main drawback of CAPM is that it assumes investors are aware of their expected returns, causing the circularity problem to appear, according to which the CAPM model informs about "what asset return interrelationships must be in order for equilibrium asset prices to coincide with the observed asset prices" 
(Danthine and Donaldson (2002), cited by Armitage (2005)). Yet the model involves realistic approaches to estimate its parameters, which are risk-free rate, market risk premium and asset's beta. The components of the CAPM equation shall be discussed later in the paper.

Indirect Approach to Cost of Capital Estimation. In most financial literature the weighted average cost of capital (WACC) is the most widely suggested as a tool to measure entity's cost of capital. The rationale behind it is that various capital sources imply different costs. Therefore, the discount rate should be weighted according to the costs of all stand-alone financing sources. From 1980s till today WACC is the most widely used tool in practice to estimate the cost of capital (McLaney et al. 2004; Bruner 1998).

One of the most traditional Weighted Average Cost of Capital equation amended by practitioners from the Global Treasury News looks as follows (Tijdhof 2006 ):

$$
W A C C=\frac{E}{D+E+H} \cdot R_{E}+\frac{D}{D+E+H} \cdot R_{D} \cdot(1-T)+\frac{H}{D+E+H} \cdot R_{H}
$$

where $\mathrm{D}$ is company's debt

$E$ is company's common equity

$R_{E} \quad-$ cost of equity

$R_{D} \quad-$ cost of debt

$T \quad-$ tax rate in economic system

$H \quad$ - company's hybrid capital

$R_{H} \quad-$ cost of hybrid capital (Tijdhof, 2006)

Hybrid capital is the capital which has characteristics of both equity and debt (preferred stock as typical example).

Application of WACC model infers several assumptions. (Bruner 1998) First, capital costs are assumed to be forward looking at spot time, and not to reflect history. Next, capital structure should be market-value based because book-value measures infer misleading results. In defence of the market-based values, Copeland (1996) also claims that in case of asset purchase asset's price should be market-based. Finally, given Equation 2, the cost of debt should be estimated after taxes due to the tax shield available in countries with traditional profit taxation. The paper shall be based on the assumption that each category of capital should be priced individually, in which case WACC is applicable.

Deducted Approach to Cost of Capital Estimation. As a deductive approach, Vernimmen (2005) suggests to infer the cost of capital via enterprise value. Vernimmen (2005) confesses that this approach is not popular since "it is difficult to determine the market consensus for free cash flows".

Continuing the discussion, authors based some of their hypotheses provided in empirical part on the several findings by Bruner (1998). First, WACC is most widely adopted as the discount rate, which makes authors to distinguish between the costs of each capital category and to weight them according to their presence in the capital structure. Secondly, CAPM is the most widely adopted to estimate the cost of equity, which allows believing that CAPM should be considered in greater details.

\section{Previous surveys on estimation of the cost of capital in practice}

Numerous papers and studies were conducted and published on the cost of capital. The authors of this paper would split them into two broad categories. Papers from the first category discuss fundamental appropriateness of already existing models in practice and elaborate them technically from a standstill of financial theory. Papers from the second category investigate which methods and approaches practitioners use to evaluate a project or to find company's value. This category comes close to the essence of this paper, whereas most of them do not aim to research and evaluate practices of cost of capital estimations in details (Armitage 2005).

One of the earliest surveys by Gitman and Mecurio (1982) was conducted among leading 177 US companies in the beginning of 1980s. McLaney, Pointon, Thomas and Tucker (2004) studied UK finance practitioners' approach to the cost of capital derivation based on responses from 193 UK quoted companies. Truong, Partington and Peat (2008) assessed capital budgeting and cost of capital practices in Australia using sample survey. The widely cited surveys on theory and practice of corporate finance by Graham, Harvey (2001) and by Brounen, de Jong, Koedijk (2004) should be mentioned; these surveys inter alia paid attention to the issues related to cost of capital estimation. However, all these surveys were conducted in countries with developed capital markets where the estimation of cost of capital usually is not associated with various 
adjustments, which have to be made when deriving the cost of capital in a country with undeveloped capital market.

In the context of this paper the survey described by Bruner (1998) will be relevant when analyzing results of the survey conducted for this paper, because Bruner's study focused on techniques and approaches to cost of capital calculation in greater details. Namely, it sought to ask the respondents which parameters they use as inputs to come to company's cost of capital. There is another relevance of the study: it may be considered as a benchmark in empirical part of this paper. In his research Bruner covered the North American region, which is generally considered as a developed capital market, and many practitioners around the world use the US data as proxy inputs in their valuations. Bruner's study was based on telephone surveys of 27 large companies and some M\&A advisers in 10 investment banks.

To bring the paper closer to Estonian conditions, the surveys by Sander (2003) and Hannula (2006) shall be cited to find out which practices were used by Estonian financial analysts previously and to trace what changes, if any, took place. The latter would be especially intriguing taking into consideration the fact that over the last few years economic conditions changed in the whole world substantially following the financial turmoil which penetrated globally since 2008.

In essence, authors expect this paper to be a wide and thorough research of Estonian valuation services market, which shall continue and expound previous studies by Sander (2003) and Hannula (2006) in terms of the number of respondents, seeking to bring out recommendations as to which inputs are relevant in the cost of capital in Estonian conditions on a forward-looking basis.

\section{Practice of cost of capital estimation in Estonia: empirical evidence}

Authors' primary contribution in this paper is evaluation of practice of cost of capital estimation for Estonian companies. To accomplish the task, the survey (hereinafter referred to as Survey 2010) has been conducted among Estonian financial analysts. The sample also involves two companies with Latvian and Lithuanian domicile. To conduct the survey, authors composed a questionnaire which was sent to companies via electronic mail following a personal telephone call to an analyst. The survey was conducted during the fall of 2010, taking a few months to collect the filled questionnaires. Because the long time was used for the survey, a high rate of response has been achieved. In total, there were 28 responses collected. In authors' opinion the sample covers a considerable range of valuation service market players, meaning that survey results may be generalized in market terms. For comparison, during the surveys in 2003 and 2006 there were 6 and 9 questionnaires collected respectively. The following companies responded:

Commercial and investment banks (7 respondents): AS SEB Enskilda, AS Swedbank, AS Cresco, AS Evli Securities, AS LHV Group, AS Trigon Capital, AS Gild Partners.

Audit companies (6 respondents): AS Deloitte Advisory, AS Ernst \& Young Baltic, OÜ KPMG Baltics, AS Pricewaterhousecoopers, OÜ Rimess, OÜ Rödl \& Partner.

Financial advisers and others (14 respondents): OÜ Advisio, Avaron, OÜ Business Advisor, OÜ Catella Corporate Finance, OÜ Emerging Market Research, AS Hanseatic Capital, Innopolis Konsultatsioonid, OÜ Investment Agency, OÜ Keystone Advisers, AS Krediidiinfo, Orion Securities, OÜ Sentio, OÜ SP Navitas, OÜ Umbrella Corporate Services.

Also authors received a response from Estonian Financial Inspection. The sample was chosen in accordance with companies' profile. Commercial and investment banks do need to perform valuation to estimate project's feasibility either for banks' uses or on customers' request. Auditing companies render advisory services to customers, including project valuation services. Financial advisory companies deal with project valuation on customers' request. The deficiency of Survey 2010 is the passive participation from the part of commercial banks, whose representatives did not wish to fill in the questionnaire.

Out of 28 respondents, 21 respondents returned the filled questionnaire. Other 7 responses were the following:

- two respondents could not fill in the questionnaire for technical reasons as they had no person who performs the valuation via discounted cash flows and thus they do not estimate cost of capital;

- one respondent does not value projects via discounted cash flows;

- one respondent refused to fill in the questionnaire for the reason of keeping its commercial secret, in which case this is the methodology used to estimate cost of capital;

- two respondents do not evaluate Estonian companies;

- one respondent provided his comments on the subject, but did not wish to fill in the questionnaire.

Among respondents who filled in the questionnaire there are: 
- one respondent who evaluates only listed companies, and

- one respondent who evaluates technology start-ups.

Thus, authors collected 21 filled questionnaires and 7 other responses.

Authors decided to conduct the analysis based on all 21 questionnaires regardless of the fact that two of them (composed for listed companies and technology start-ups) diverge to some extent from the context of an average Estonian non-listed company. However, this fact shall be taken into account and the notes on that shall be made when necessary. The reason to include those questionnaires into analysis is the fact, that the basic approaches stay similar to those for the average Estonian non-listed company. The points at which potential conflicts may arise shall be pointed out during analysis.

In 2003 Priit Sander and in 2006 Ann Hannula conducted similar surveys among financial analysts to figure out and evaluate the practice of cost of capital estimation for Estonian companies. Priit Sander (2003) collected 6 questionnaires and Hannula (2006) collected 9 questionnaires from banks and auditing companies. The financial collapse of 2008 had a trembling effect on stock markets, which in turn confused analysts. Indeed, some politicians and economists believe the world has changed drastically and there is no point of return. For instance, the financial guru George Soros (2008) in his book «The New Paradigm for Financial Markets» expounded his view of how the financial markets are functioning, and he proposes that albeit previously happened financial bubbles were prone to revert to the so called 'normal conditions', or equilibrium, the financial distress of 2008 will not. This may imply that analysts are facing with greater uncertainties about the markets. Also, one survey respondent provided an opinion that the artificially or wrongfully estimated cost of capital turned to be one of the most important factors which caused the financial distress, and, as a matter of fact, in today's conditions he believes it may cause the next financial distress. Today, in financial crisis aftermath, authors find it very interesting to learn how financial practices have changed since previous studies by Sander and Hannula. Besides that, authors found it would be justified to research the entire advisory market to learn about approaches to cost of capital estimation. To do this, a wider range of respondents was targeted, including the smaller financial advisory companies.

In this work the following hypotheses were set to test:

1. When estimating the cost of capital, the heterogeneity about corporate income taxation issues exists among analysts, resulting in confusing practices.

2. The primary approach to cost of equity estimation is CAPM.

3. After the financial turmoil the tendency towards using inputs from mature markets has strengthened, and the tendency towards using inputs from emerging markets has weakened.

4. There is no prevalent approach to cost of debt estimation.

5. Analysts tend to neglect country and currency risks, and other risks are rather reflected as a discount from the final value.

6. New approaches in cost of capital estimation have emerged.

In essence, the questionnaire was composed on the basis of questionnaire by Sander (2003), who sent it to authors by e-mail. The questionnaire consisted of six parts and included 22 multiple choice questions.

Part I of the questionnaire involved few questions about an analyst to learn his/her background and experience. Part II is concerned with general principles of cost of capital estimation, such as which capital categories analysts consider to be the part of capital structure, which weighting factors they use, and how they treat taxes and transaction costs. Part III of the questionnaire scrutinizes cost of equity estimation. This part seeks to learn which methods analysts use in their valuation to estimate the cost of equity. It should be noted that this questionnaire targets traditional CAPM model. First, it asks which methodologies analysts use and given the rank. The following questions consider the CAPM model and its components to figure out which inputs analysts refer to in case they use CAPM. The reason to base the questionnaire on the CAPM model was its great popularity among Estonian analysts revealed previously. The survey results proved this assumption right. Part IV asks about approaches to estimation of cost of debt. Part V considers estimation of cost of hybrid capital. It is asked if analysts had cases of hybrid capital cost estimation. Part VI considers adjustments to discount rate. In the framework of cost of capital, authors ask if analysts adjust cost of capital for country risk and currency risk. To accomplish the study, authors have decided to add few questions on traditionally used discounts and premiums, such as small size discount/premium, illiquidity discount/premium, and key person discount/premium. 


\section{Results of the author's survey}

The total number of questionnaire respondents is 21 . The average age of the analysts is 31 years; the average experience in valuation is 7 years. Among them, there are 13 Bachelor degree holders and 8 Masters Degree holders. According to the voluntarily mentioned information, one BA degree holder holds a CFA charter, one Master's degree holder is a PhD program student. It is difficult to bring out the average number of valuation cases performed by an average analyst over one year. The most often mentioned were over 20 cases ( 6 respondents), plus from 6 till 10 cases and below 3 cases (5 respondents per each spread).

Speaking about results, then first of all, authors assumed that tax-related aspects are confusing to analysts, as a result of which there is heterogeneity when applying them. Provided Estonian tax legislation is different from traditional tax legislations in developed countries, Sander (2003) reported that one third of the analysts apply a tax rate to equity, one third apply it to debt, and one third neglect taxes. In 2010 the share of analysts who neglect taxes reached $55 \% .27 \%$ of respondents apply taxes to debt, $9 \%$ apply taxes to equity, and $9 \%$ apply, but did not specify in which way. The tendency towards neglecting taxes starts to appear, on the one hand. On the other hand, there are still some opinion conflicts occur as to how to integrate taxes into the WACC equation in case an analyst decides to do that. Proceeding from features of Estonian system of corporate income taxation we propose to ignore taxes in WACC estimations for fair and transparent valuation. If one has doubts, it is better to use after-tax WACC and after-tax cash flows

Second, authors' hypothesis was that the primary approach to cost of equity estimation is Capital Asset Pricing Model. Previously, in Sander (2003) and Hannula (2006), up to 80\% of the analysts used CAPM as a primary tool. In 2010 we had the same tendency: in up to $82 \%$ of cases CAPM is a primary tool to estimate the cost of equity. It should be noted that Bruner (1998) reported similar findings among the US advisers. Penetration rate of CAPM is high presumably due to its convenience and applicability in real conditions, when all inputs can be estimated based on the capital market. This view is fully supported by the authors.

Third, authors assumed that after the financial turmoil, which shook global markets, a tendency towards using mature market inputs should appear. Albeit according to surveys in 2003 and 2006 analysts used developed market inputs, this tendency has become stronger. By 2010, however, the tendency towards European inputs, especially German inputs, had increased (for instance, as there are no long-term government bonds available in Estonia, the yields on long-term German bunds are used as proxies for riskfree rate). Authors support reliance on European markets to derive the estimates for Estonian development patterns following the European patterns of development. In addition, European inputs ensure the currency match in the estimations.

Another hypothesis set up prior to survey was that there is no prevalent approach to cost of debt estimation. In 2010 in $48 \%$ of cases interest rate on existing liabilities and in $16 \%$ a marginal cost was used. Thus, albeit an interest rate on existing liabilities is a dominant approach, there is still no prevailing approach. In author's opinion marginal cost is the best approach to estimate the cost of debt because the company is estimated based on a going concern, in which case a prospective approach should be applied.

Also authors assumed that analysts tend to neglect country and currency risks, whereas other risks are rather reflected via discount from the final value. The survey, however, showed that in $59 \%$ of cases analysts do account for the country risk, whereas only in $19 \%$ they do account for the currency risk. As for the other risks, such as company's small size, illiquidity and key person, approaches are scattered unevenly in some cases in favor of the discount from the final value, and in others in favor of premium in the discount rate.

Last, authors assumed there must have been new approaches emerged. From our survey we distinguish between two newly arising approaches, which are the use of Estonian Credit Default Swaps (CDS) to adjust inputs, and adjustment of a risk-free rate for the country risk which was not reported previously. Nevertheless, adjustment of risk-free rate takes place not to reflect country risk per se but to add a premium for the risk which would rather correspond to Estonian sovereign bonds because the yield on German sovereign bonds is adjusted by CDS to infer the risk-free rate for Estonian companies. Authors are curious about the implications of CDS market; those implications deserve another research to be clarified.

\section{Conclusions}

1. Approaches to the cost of capital estimation among Estonian financial analysts are mixed although it is possible to bring out some common elements. Whilst it is possible to state that capital asset pricing 
model is leading approach in cost of equity estimation there is diverse approach to cost of debt derivation.

2. In most of the cases analysts neglect taxes-related aspects but account for country risk. Regarding other risk adjustments the practice is quite scattered: in some cases risks are discounted from final valuation, in some cases they are added as premium to discount rate.

3. It is possible to state the emergence of new approaches. There is practice of using Estonian credit default swaps to adjust inputs, and the practice of adjustment of risk-free rate for country risk which was not reported in previous surveys.

4. In our opinion the results can be used by financial analysts in their cost of capital estimations for Estonian companies to adhere to the trends and infer compatible estimates. The limitation, however, would be changing economic conditions, in which case recommendations should be validated from time to time. Which inputs to use as proxies for different indicators is still an open issue.

\section{References}

1. Armitage, S. (2005). The Cost of Capital. Intermediate Theory. Cambridge University Press. 353p.

2. Brounen, D., de Jong, A., Koedijk, K. (2004) Corporate Finance in Europe: Confronting Theory with Practice. Financial Management, Winter, 71-101

3. Bruner, R. F., Eades, K. M., Harris, R. S., Higgins, R. C. (1998). Best Practices in Estimating the Cost of Capital: Survey and Synthesis. Financial practice and education - Spring/Summer, 13-28

4. Copeland T. E., Weston, J. F. (1988). Financial Theory and Corporate Policy. $3^{\text {rd }}$ ed. New York: Addison-Wesley.

5. Copeland T.E.. (1996). Valuation: Measuring and Managing the Value of Companies. $2^{\text {nd }}$ ed. New York: Wiley.

6. Damodaran, A. (2002). Investment Valuation. $2^{\text {nd }}$ ed. New York: John Wiley.

7. Gitman, L. J., Mercurio, V. A. (1982). Cost of Capital Techniques Used by Major U.S. Firms: Survey and Analysis of Fortune's 1000. Financial Management, Winter, 21-29

8. Graham, J. R., Harvey, C. R. (2001) The theory and practice of corporate finance: evidence from the field. Journal of Financial Economics, 60, 187-243

9. Hannula, A. (2006). Kapitali hinna määramine börsil noteerimata Eesti ettevõtete hindamisel, unpublished BA thesis. Tallinn University of Technology: Faculty of Economics and Business Administration.

10. McLaney, E., Pointon, J., Thomas, M., Tucker, J. (2004). Practitioners' perspectives on the UK cost of capital. The European Journal of Finance, 10(2), 123-138

11. Sander, P. (2003). Estimating the Cost of Capital in Transition Markets: Estonian Experiences. Finance in EU Accession Countries: Experiences and Solutions, Conference Proceedings, Vol. 1., 188-199.

12. Sharpe, W. F. (1964). Capital Asset Prices: A Theory of Market Equilibrium under Conditions of Risk. Journal of Finance, 19(3), 425-442.

13. Soros, G. (2008). The New Paradigm for Financial Markets. The Credit Crisis of 2008 and What it Means. New York: Public Affairs.

14. Tijdhof, L. (2006) WACC: Practical Guide for Strategic Decision-Making. Part 1: Is Estimating the WACC Like Interpreting a Piece of Art? [http://www.zanders.nl/publicaties/documents/WACC_part1.pdf] (25.09.2010)

15. Truong, G., Partington, G., Peat, M. (2008). Cost-of-Capital Estimation and Capital-Budgeting Practice in Australia. Australian Journal of Management, 33(1), 95-121

16. Vernimmen, P., Quiry, P., Le Fur, Y., Dallocchio, M., Salvi, A. (2005). Corporate Finance. Theory and Practice. $6^{\text {th }}$ ed. New York: John Wiley. 